\title{
Ti-rich plagioclase-phyric dykes of southern West Greenland
}

\author{
R. P. Hall, D. J. Hughes and C. R. L. Friend
}

The investigation of Proterozoic basic dykes in southern West Greenland stemmed from the programme of systematic mapping of the Archaean craton in that region by the Geological Survey of Greenland (GGU). This work began in the southern Frederikshåb region in the early 1960s (Jensen, 1968, 1969) and progressed northwards, from bases in the Fiskenæsset (Kalsbeek \& Myers, 1973; GGU, 1976), Godthåb (Allaart et al., 1977) and Sukkertoppen areas (Allaart et al., 1978). The results of most of this mapping work were summarized by Bridgwater $e$ al . (1976) and compiled onto a 1:500 000 scale geological map sheet by Allaart (1982). The distribution of the major Proterozoic dykes which cut the entire region is shown on this map. While the basic dykes are individually minor intrusions, many are up to 50 metres wide and continuous for several tens of kilometres, and collectively they represent a major magmatic event. As many of the Archaean terrains of the world possess Proterozoic basic dyke swarms, their compositions are crucial to a correlation of events from one craton to another and to an understanding of crustal and mantle evolution after the world-wide late Archaean sialic crust-forming event.

This report illustrates that the doleritic dykes of West Greenland are not a simple, single evolving suite as has been thought previously. The work is based on an arranged programme of geochemical analysis of basic rocks from Greenland collected by the authors during field work undertaken on behalf of GGU. The analysis was carried out by X-ray fluorescence spectrometry in the Department of Geology at Portsmouth Polytechnic, analytical procedures and earlier findings having been presented elsewhere (Hall \& Hughes, 1986; Hall et al., 1985, 1986, in press).

The majority of the basic dykes comprise dolerite, variably deuterically altered to amphibole- and epidote-bearing assemblages. They have previously been collectively termed the MD (meta-dolerite) dykes (Bridgwater et al., 1976) and different generations have been identified by their cross-cutting field relationships, orientation and geochemistry. The successive generations of MD dykes (MD1, MD2, MD3) are progressively more evolved, and they define what has been considered to be a common tholeiitic trend (Rivalenti, 1975; Hall et al., 1985). However, norite dykes become more abundant in the northern part of the Archaean craton and although they were previously considered to be part of the oldest generation (MD1) of the MD dykes (Bridgwater et al., 1976; Hall et al., 1985), it was shown recently that in fact they comprise a petrogenetically discrete swarm and that they are not related to the MD dykes (Hall \& Hughes, 1986). MD1 dolerites are extremely rare.

The youngest of the basic dykes have previously been referred to as MD3b dykes (Friend, 1975) because they share the same orientation (E-W to SE-NW) as the other MD3a dykes (Dawes, 1970; Bridgwater et al., 1976). They are, however, clearly distinguishable from the MD3a dykes both petrographically and geochemically (Hall et al., 1985). They are characterized by the presence of large (up to $200 \mathrm{~mm}$ ) zoned plagioclase phenocrysts $\left(\mathrm{An}_{55-30}\right)$, typically in a fine-grained doleritic groundmass which commonly contains concentrically zoned hypersthene - pigeonite - augite/ferroaugite pyroxenes. The other MD dykes comprise ap- 
Table 1. Geochemistry of representative MD dolerites (1-5) and plagioclase-phyric (PP) dykes (6-8)

\begin{tabular}{|c|c|c|c|c|c|c|c|c|}
\hline & 1 & 2 & 3 & 4 & 5 & 6 & 7 & 8 \\
\hline Dyke & MD1 & MD2 & MD2 & MD3 & MD3 & PP & PP & PP \\
\hline GGU No. & 94524 & 120503 & 149208 & 179032 & 179092 & 119861 & 120528 & 120351 \\
\hline \multicolumn{9}{|l|}{$w t \%$} \\
\hline $\mathrm{SiO}_{2}$ & 49.97 & 47.32 & 46.39 & 48.97 & 49.48 & 49.79 & 51.52 & 52.37 \\
\hline $\mathrm{Al}_{2} \mathrm{O}_{3}$ & 16.99 & 16.67 & 16.23 & 14.85 & 13.56 & 13.09 & 13.53 & 16.41 \\
\hline $\mathrm{Fe}_{2} \mathrm{O}_{3}$ & 1.62 & 0.53 & 3.43 & 2.91 & 3.39 & 3.77 & 2.93 & 1.50 \\
\hline $\mathrm{FeO}$ & 6.65 & 10.86 & 9.99 & 11.03 & 12.85 & 11.10 & 10.66 & 9.10 \\
\hline $\mathrm{MgO}$ & 9.24 & 9.08 & 8.45 & 6.72 & 5.54 & 5.76 & 5.36 & 3.83 \\
\hline $\mathrm{CaO}$ & 12.63 & 12.46 & 11.89 & 10.86 & 9.11 & 8.23 & 7.46 & 8.60 \\
\hline $\mathrm{Na}_{2} \mathrm{O}$ & 1.71 & 1.75 & 1.96 & 2.37 & 2.62 & 2.76 & 3.47 & 3.89 \\
\hline $\mathrm{K}_{2} \mathrm{O}$ & 0.32 & 0.17 & 0.22 & 0.52 & 0.63 & 1.32 & 1.51 & 1.24 \\
\hline $\mathrm{TiO}_{2}$ & 0.56 & 0.79 & 1.04 & 1.16 & 2.10 & 3.08 & 2.77 & 2.18 \\
\hline $\mathrm{MnO}$ & 0.19 & 0.21 & 0.22 & 0.23 & 0.25 & 0.24 & 0.18 & 0.17 \\
\hline $\mathrm{P}_{2} \mathrm{O}_{5}$ & 0.10 & 0.15 & 0.17 & 0.20 & 0.24 & 0.85 & 0.62 & 0.69 \\
\hline Total & 100.42 & 100.38 & 100.18 & 100.11 & 99.90 & 99.75 & 100.01 & 100.76 \\
\hline \multicolumn{9}{|l|}{$p p m$} \\
\hline $\mathrm{Sc}$ & 34 & 43 & 42 & 45 & 43 & 32 & 25 & 21 \\
\hline V & 202 & 247 & 268 & 323 & 536 & 291 & 228 & 152 \\
\hline $\mathrm{Cr}$ & 278 & 219 & 151 & 52 & 25 & 48 & 38 & 36 \\
\hline $\mathrm{Ni}$ & 224 & 122 & 111 & 74 & 41 & 23 & 26 & 32 \\
\hline $\mathrm{Cu}$ & 85 & 76 & 104 & 256 & 386 & 14 & nd & 1 \\
\hline $\mathrm{Rb}$ & 17 & 18 & 15 & 9 & 17 & 32 & 8 & 4 \\
\hline $\mathrm{Sr}$ & 191 & 115 & 141 & 205 & 151 & 334 & 435 & 509 \\
\hline $\mathrm{Y}$ & 27 & 26 & 25 & 19 & 30 & 34 & 25 & 22 \\
\hline $\mathrm{Zr}$ & 52 & 40 & 53 & 61 & 109 & 243 & 210 & 191 \\
\hline $\mathrm{Nb}$ & 1 & nd & 2 & 4 & 6 & 39 & 13 & 14 \\
\hline $\mathrm{Ba}$ & 132 & 41 & 56 & 129 & 149 & 875 & 762 & 803 \\
\hline $\mathrm{La}$ & 4 & 3 & 4 & 9 & 10 & 45 & 29 & 28 \\
\hline
\end{tabular}

XRF major element analyses recalculated to $100 \%$ on a water-free basis.

Totals are original XRF totals.

nd not determined.

hyric ophitic or sub-ophitic dolerites which contain less regularly but more extremely zoned pyroxenes (Hall et al., 1986).

The plagioclase-phyric dykes (henceforth referred to as the PP dykes) are geochemically distinguishable in that they are clearly far more evolved in many respects than the MD dolerites (Table 1). They have the lowest levels of $\mathrm{Mg}, \mathrm{Ni}, \mathrm{Cr}$ and $\mathrm{Ca}$ and the highest levels of $\mathrm{Si}$, $\mathrm{K}, \mathrm{Na}, \mathrm{Ba}, \mathrm{Sr}, \mathrm{Zr}, \mathrm{P}, \mathrm{Nb}$ and light rare-earth elements (REE). One of their geochemical characteristics is that they are also relatively rich in $\mathrm{TiO}_{2}$ (2.2 to 3.3\%). On many commonly used geochemical evolution diagrams (e.g. elements plotted against $\mathrm{MgO}, m g$ number or $\mathrm{SiO}_{2}$ ) they appear to fall at the evolved end of the geochemical trend defined by the MD dolerites. However, there are several important differences between the geochemical trends of the PP dykes and the MD dolerites, which suggest that they are not petrogenetically related to each other by a simple fractionation process, and that they probably constitute discrete magmatic suites. Some of these differences are best illustrated with reference to the $\mathrm{TiO}_{2}$ contents of the dykes (fig. 1). 


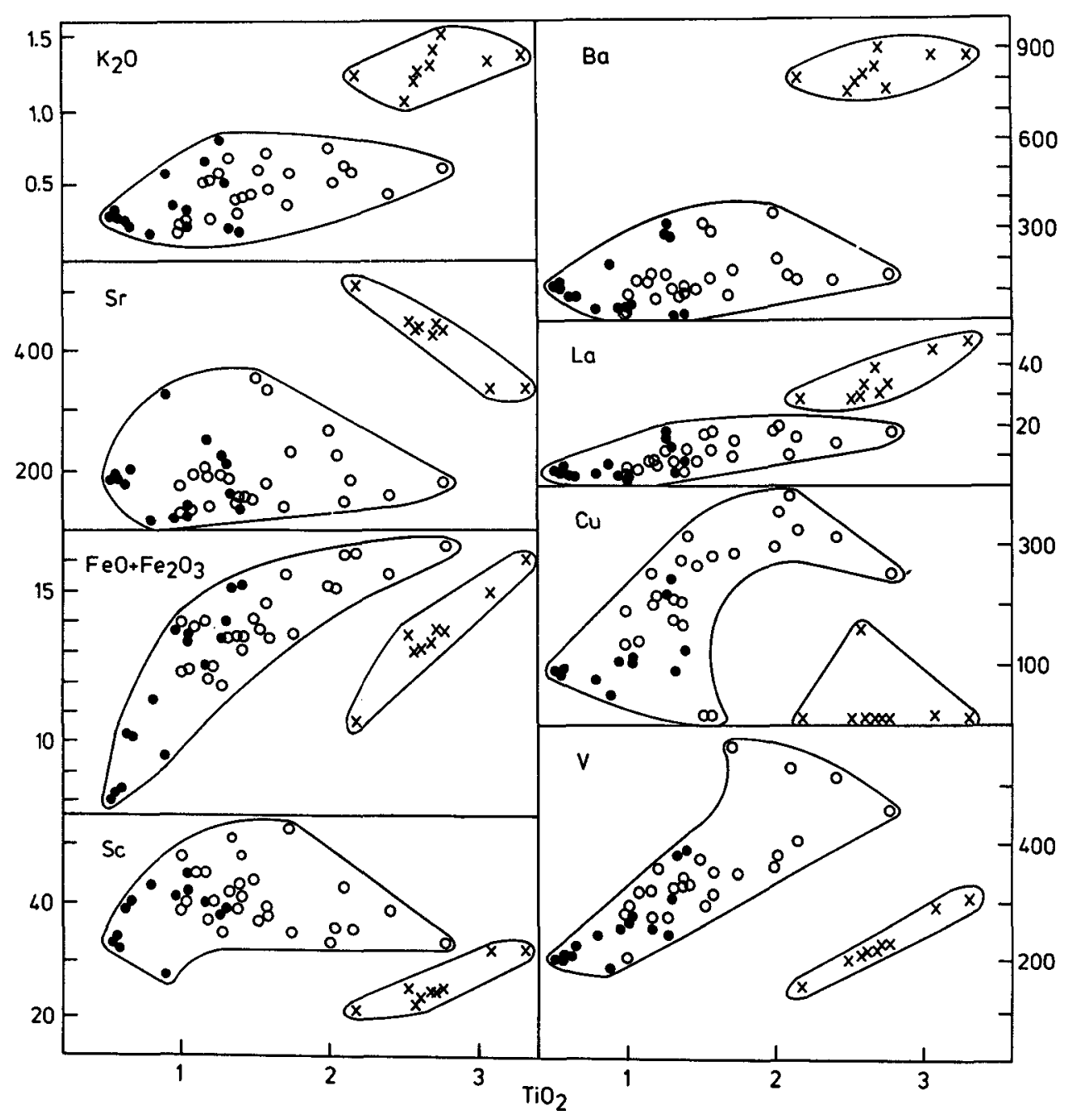

Fig. 1. Abundances of $\mathrm{K}_{2} \mathrm{O}$ and $\left(\mathrm{FeO}+\mathrm{Fe}_{2} \mathrm{O}_{3}\right)(w t \%)$, and $\mathrm{Ba}, \mathrm{Sr}, \mathrm{La}, \mathrm{Cu}$ and $\mathrm{V}$ (ppm) plotted against $\mathrm{TiO}_{2}$ (wt \%) in the MD1 and MD2 (dots) and MD3 (open circles) dolerites and the plagioclase-phyric (PP) dykes (crosses) illustrating the large differences between the geochemical trends of the two groups of dykes.

The $\mathrm{TiO}_{2}$ contents of the MD dykes increase sequentially from 0.5 to $2.7 \%$. The levels of $\mathrm{Si}, \mathrm{Sr}, \mathrm{Ba}$ and the alkali and light REE (e.g. La) are significantly lower in the most evolved of the MD dykes than in the relatively Ti-rich PP dykes, although they have similar $\mathrm{MgO}$ contents (Table 1). Conversely, the $\mathrm{Fe}, \mathrm{Cu}, \mathrm{Sc}$ and $\mathrm{V}$ concentrations are relatively lower in the PP dykes, and these elements clearly do not plot as an extension of the MD dykes geochemical trend (fig. 1) but suggest a separate evolutionary history for the PP dykes. The relatively low Fe and high $\mathrm{K}$ contents of the PP dykes are also reflected by their different AFM 
Fig. 2. $\left(\mathrm{Na}_{2} \mathrm{O}+\mathrm{K}_{2} \mathrm{O}\right):(\mathrm{FeO}$ $+\mathrm{Fe}_{2} \mathrm{O}_{3}$ ): $\mathrm{MgO}$ (AFM) plot illustrating the different chemical characters of the doleritic (MD), plagioclasephyric (PP) and noritic (BN) dykes of southern West Greenland. The PP dykes clearly show an alkali-enrichment trend at a lower $\mathrm{Fe}: \mathrm{Mg}$ ratio than the $M D$ dykes (symbols as in fig. 1), and the BN dykes (V) do not show marked Fe-enrichment. MD dyke data from Hall et al. (1985) and Rivalenti (1975); BN data from Hall \& Hughes (1986). The dashed line separates the fields of tholeiitic rocks which have an Fe-enrichment trend (above the line) and calc-alkali suites (below the line) and is taken from Irvine \& Baragar (1971).

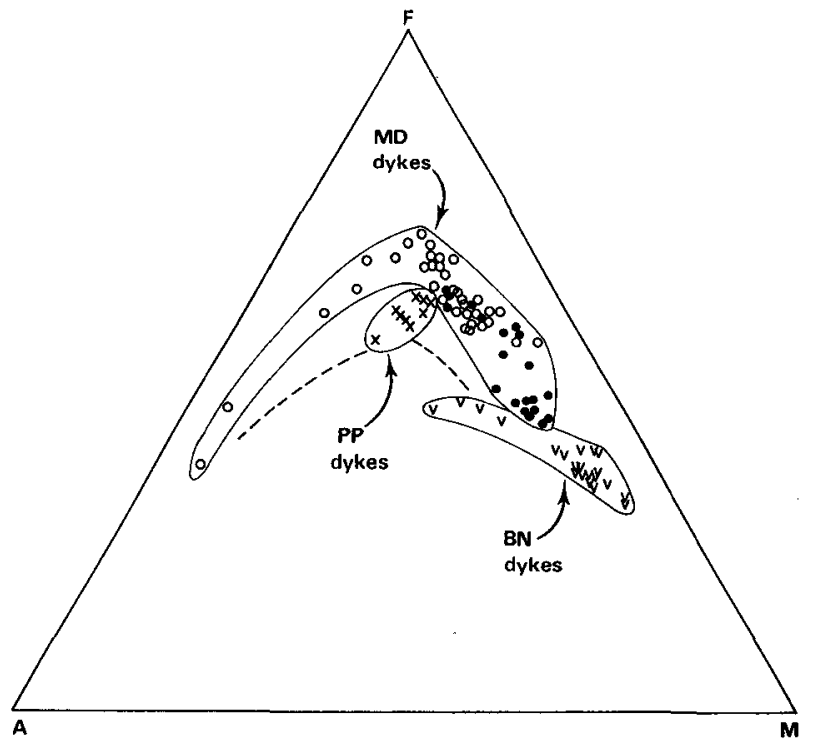

proportions compared to the well defined Fe-enrichment trend of the MD dolerites (fig. 2). One MD3 dyke sample described by Rivalenti (1975) plots in the PP dykes field in the AFM diagram and this sample ( $33=$ GGU 85338$)$ is slightly unusual in that it has anomalously high $\mathrm{Na}$ and normative albite contents compared to the other MD dykes with similar $\mathrm{Mg} / \mathrm{Fe}$ values. Its position on the AFM plot is, therefore, also considered to be anomalous (and is not shown in fig. 2).

No simple fractional crystallization model can accommodate these large geochemical differences. The plagioclase-phyric character of the younger Ti-rich dykes suggests that plagioclase accumulation might have been responsible for the distinctive geochemistry of the PP dykes. While the accumulation of plagioclase into an MD3a-type liquid could account for an increase in $\mathrm{Ba}, \mathrm{Sr}$ and $\mathrm{Na}$ levels, the concentration of plagioclase phenocrysts $(<10 \%)$ in the analysed samples is insufficient to explain the observed difference in, for example, Ba (an increase from c. 250 to $800 \mathrm{ppm}$ ), and plagioclase accumulation does not account for the high $\mathrm{K}$ and low $\mathrm{Ca}$ contents of the PP dykes.

The different levels of $\mathrm{Fe}, \mathrm{Sc}, \mathrm{V}$ and $\mathrm{Cu}$ in the MD and PP dykes (fig. 1) could simply reflect differences in either source compositions or the rates of precipitation of clinopyroxene, magnetite and a sulphide phase such as chalcopyrite, partly controlled by variations in the fugacity of oxygen and sulphur $\left(f_{\mathrm{O}_{2}}\right.$ and $\left.f_{\mathrm{S}_{2}}\right)$. The relatively low Fe content of the $\mathrm{P}$ dykes indicates that magnetite had previously precipitated from their parental magma as a result of a relatively higher $f_{\mathrm{O}_{2}}$. A lower $f_{\mathrm{O}_{2}}$ in the magma feeding the MD dykes is implied by the latestage precipitation of magnetite and the extreme compositional complexity of their pyrox- 


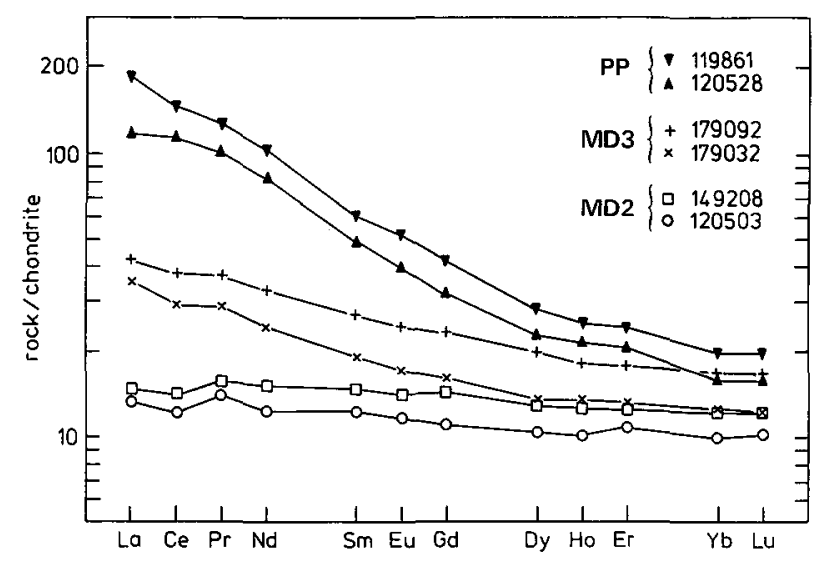

Fig. 3. REE abundances normalized to average $\mathrm{CI}$ chondrite (Evensen et al., 1978) in two MD2 dolerites (GGU 120503 and 149208), two MD3 dolerites (GGU 179032 and 179092) and two plagioclase-phyric dykes (GGU 120528 and 119861). Geochemical analyses of these samples are included in Table 1.

enes (Hall et al., 1986). The relative abundances of V and Sc support this interpretation. Similarly, the extremely low concentration of $\mathrm{Cu}$ in all but one of the PP dykes is probably accounted for by the early removal of chalcopyrite, effected by a relatively high $f_{\mathrm{S}_{2}}$, in contrast to the lower $f_{\mathrm{S}_{2}}$ of the MD dyke magma inferred from the increasingly high Cu content (up to $400 \mathrm{ppm}$ ) and thus failure of chalcopyrite precipitation in these dykes.

A fractionation model relating the PP to the MD dykes, therefore has to be a complex one including the removal of clinopyroxene, magnetite and chalcopyrite in conjunction with plagioclase accumulation and still cannot account for such features as the high $\mathrm{K}$ and $\mathrm{Ba}$ and low Ca contents of the PP dykes. The lack of a geochemical continuum from the MD dolerites to the PP dykes, and their separate but parallel geochemical trends with respect to certrast to the lower $f_{\mathrm{S}_{2}}$ of the MD dyke magma inferred from the increasingly high $\mathrm{Cu}$ content (up to $400 \mathrm{ppm}$ ) and thus failure of chalcopyrite precipitation in these dykes.

The break between the petrogenetic trends of the MD dykes and the PP dykes is substantiated by equally large differences in their respective REE abundances. The aphyric MD dolerites have relatively flat, unfractionated chondrite-normalized REE abundance patterns (fig. 3), with REE contents approximately 10 to 40 times those of average CI chondrite (Evensen et al., 1978). In contrast, the PP dykes have strongly fractionated REE patterns with light REE abundances between 100 and 200 times chondritic levels. They do not, however, possess $\mathrm{Eu}$ anomalies which usually accompany plagioclase fractionation, which strongly suggests that the plagioclase phenocrysts have not accumulated in these dykes but are a primary crystallization feature occurring in original proportions.

It seems most likely, therefore, that the PP dykes crystallized from a discrete magma to that of the main MD dyke evolutionary trend. Different degrees of partial melting of the same mantle source which produced the tholeiitic MD dykes magma, or different high pressure fractionation or wall rock interaction regimes might account for the geochemical differences. However, heterogeneity of the mantle has been demonstrated to be the most likely explanation for the origin of other members of Proterozoic basic magmatic suites (Hall et al., in press), for example the noritic and doleritic intrusions (the BN and MD dykes) in West Greenland (Hall \& Hughes, 1986). Therefore, slight differences in source mantle compositions may also have played a significant role in the generation of the MD and PP dykes. 
Until recently, the norite, aphyric dolerite and plagioclase-phyric dolerite dykes were all considered to be part of the same swarm - the MD dykes. Geochemical evidence presented in a previous report (Hall \& Hughes, 1986) and in this work shows that these three types of dykes probably constitute separate swarms with different geochemical as well as petrographic characteristics. The possibility cannot be ignored that the MD and PP dyke swarms may be totally unrelated temporally as well as geochemically. For example, they may be related to the 1650-1350 m.y. feldspar-phyric dykes which occur further to the south in the Frederikshåb - Ivigtut region (Bridgwater et al., 1976), whereas the MD dykes so far investigated have yielded an age of c. 2,130 m.y. (Kalsbeek \& Taylor, 1985). An isotopic investigation would clearly help to resolve the problem of the age and origin of these plagioclasephyric dykes.

\section{References}

Allaart, J. H. (compiler) 1982: Geologisk kort over Grønland, 1:500 000, Sheet 2 Frederikshåbs Isblink - Søndre Strømfjord. Copenhagen: Geol. Surv. Greenland.

Allaart, J. H., Jensen, S. B., McGregor, V. R. \& Walton, B. J. 1977: Reconnaissance mapping for the 1:500 000 map sheet in the Godthåb - Isua region, southern West Greenland. Rapp. Grønlands geol. Unders. 85, 50-54.

Allaart, J. H., Friend, C. R. L., Hall, R. P., Jensen, S. B. \& Roberts, I. 1978: Continued 1:500 000 reconnaissance mapping in the Precambrian of the Sukkertoppen region, southern West Greenland. Rapp. Grønlands geol. Unders. 90, 50-54.

Bridgwater, D., Keto, L., McGregor, V. R. \& Myers, J. S. 1976: Archaean gneiss complex of Greenland. In Escher, A. \& Watt, W. S. (edit.) Geology of Greenland, 18-75. Copenhagen: Geol. Surv. Greenland.

Dawes, P. R. 1970: Bedrock geology of the nunataks and semi-nunataks in the Frederikshåbs Isblink area of southern West Greenland. Rapp. Grønlands geol Unders. 29, 60pp.

Evensen, N. M., Hamilton, P. J. \& O'Nions, R. K. 1978: Rare-earth abundances in chondritic meteorites. Geochim. cosmochim. Acta 42, 1199-1212.

Friend, C. R. L. 1975: The geology and geochemistry of the Preketilidian basement complex in the Ravns Storø area, Fiskenæsset region, southern West Greenland. Unpubl. Ph.D. thesis, Univ. London.

GGU 1976: Second progress report on the geology of the Fiskenæsset region, South-West Greenland. Rapp. Grønlands geol. Unders. 73, 108pp.

Hall, R. P. \& Hughes, D. J. 1986: A boninitic dyke in the eastern Sukkertoppen region: geochemistry of the boninitic-noritic dyke swarm of southern West Greenland. Rapp. Grønlands geol. Unders. 130, 44-52.

Hall, R. P., Hughes, D. J. \& Friend, C. R. L. 1985: Geochemical evolution and unusual pyroxene chemistry of the MD tholeiite dyke swarm from the Archaean craton of southern West Greenland. $J$. Petrol. 26, 253-282.

Hall, R. P., Hughes, D. J. \& Friend, C. R. L. 1986: Complex sequential pyroxene growth in tholeiitic hypabyssal rocks from southern West Greenland. Mineral. Mag. 50, 491-502.

Hall, R. P., Hughes, D. J., Friend, C. R. L. \& Snyder, G. S. in press: Early Proterozoic mantle heterogeneity: geochemical evidence from contrasting basic dykes. In Pharoah, T. C., Beckinsale, R. D. \& Rickard, D. T. (edit.) Geochemistry and mineralisation of Proterozoic volcanic suites; Spec. Publ. geol. Soc. London.

Irvine, T. N. \& Baragar, W. R. A. 1971: A guide to the chemical classification of the common volcanic rocks. Can. J. Earth Sci. 8, 523-548. 
Jensen, S. B. 1968: Field work in the Frederikshåb area. Rapp. Grønlands geol. Unders. 15, 40-44.

Jensen, S. B. 1969: Field work in the Frederikshåb district. Rapp. Grønlands geol. Unders. 19, 33-35.

Kalsbeek, F. \& Myers, J. S. 1973: The geology of the Fiskenæsset region. Rapp. Grønlands geol. Unders. 51, 5-18.

Kalsbeek, F. \& Taylor, P. N. 1985: Age and origin of early Proterozoic dolerite dykes in South-West Greenland. Contrib. Mineral. Petrol. 89, 307-316.

Rivalenti, G. 1975: Chemistry and differentiation of mafic dykes in an area near Fiskenæsset, West Greenland. Can. J. Earth Sci. 12, 721-730.

R. P. H. \& D. J. H.,

Department of Geology,

Portsmouth Polytechnic,

Burnaby Road,

Portsmouth, PO1 3QL,

U.K.
C. R. L.F, Department of Geol. and Phys. Sci., Oxford Polytechnic, Headington, Oxford $O X 3 O B P$ U.K.

\title{
Reconnaissance for noble and base metal mineralisation within the Precambrian supracrustal sequences in the Ivigtut-Kobberminebugt region, South-West Greenland
}

\author{
K. Secher and P. Kalvig
}

The field programme in the Ivigtut-Kobberminebugt region is a continuation of the investigation of gold occurrences in the Tartoq Group greenstones, just north of the present area (Appel \& Secher, 1984; Appel, 1984). The region was mapped by GGU in the late 1950s and early 1960s (Henriksen, 1969; Berthelsen \& Henriksen 1975; Harry \& Pulvertaft, 1963). The Tartoq and the Ketilidian supracrustal belts were described (Allaart, 1976; Bridgwater et al., 1976); they form regional curved structures around the Arsuk Basin. The major part of the supracrustal sequences south of the Tartoq Group units is expected to be of Ketilidian (Proterozoic) age and deformation. However, some layers in the Nunarssuit peninsula in the southernmost part of the region are undated and might be older (Bridgwater et al., 1973; Appel \& Secher, 1984).

The investigation was focussed on the supracrustal sequence between Arsuk Fjord and Nunarssuit (fig. 1), with special emphasis on the areas neighbouring the known gold showings at Josva Mine (worked 1910-15) where discrete grains of electrum and gold in the bornite ore were reported by Harry \& Oen (1964). In the Kinâlik peninsula a skarn boulder with a few grains of gold included in chalcopyrite has been reported by Kryolitselskabet $\emptyset$ resund A/S (Nielsen, 1976).

The work was based on reconnaissance rock sampling of lithologies and mineral showings within the supracrustal sequences, with particular attention given to transitions between sedimentary and volcanic suites and to structural breaks in order to locate potential sources of noble metals. 